\title{
Rickets in white-eared opossums (Didelphis albiventris) ${ }^{1}$
}

\author{
Jair A. Ferreira Júnior ${ }^{2}$, Marina F. Landi ${ }^{3}$, Ariane O. Passos ${ }^{4}$, Karla A. Nascimento ${ }^{2}$, \\ João Paulo M.V.B Azevedo ${ }^{2}$, Juliana T.S.A. Macêdo ${ }^{2}$ and Pedro M.O. Pedroso ${ }^{2 *}$ (D)
}

\begin{abstract}
Ferreira Júnior J.A., Landi M.F., Passos A.O., Nascimento K.A., Azevedo J.P.M.B.V., Macêdo J.T.S.A. \& Pedroso P.M.O. 2020. Rickets in white-eared opossums (Didelphis albiventris). Pesquisa Veterinária Brasileira 40(10):814-817. Laboratório de Patologia Veterinária, Universidade de Brasília, Campus Universitário Darcy Ribeiro, Via L4 Norte $s \backslash n$, Brasília, DF 70910-970, Brazil. E-mail: pedrosovet@yahoo.com.br

Two young opossums were necropsied and diagnosed with rickets. This study aims to describe the clinical-pathological aspects of rickets in Didelphis albiventris. Macroscopically, the opossums presented kyphosis and scoliosis, lateral deviation of the limbs in varus, locomotion difficulty, and enlargement with softening of costochondral junctions (rickety rosary). Samples of bones and joints were processed for hematoxylin and eosin staining and Masson's trichrome. Microscopically, we observed thickening of the epiphyseal plate, characterized by irregular and multifocal proliferation of serialized and hypertrophic cartilage zones, which formed circular groups of large, dysplastic chondrocytes towards the spongy zone, often surrounded by non-mineralized osteoid tissue. In the cortical bone, there were pale eosinophilic zones around the Havers channels consistent with non-mineralized osteoid. The staining of Masson's trichrome evidenced the accumulation of osteoid tissue in cortical and trabecular bones. It is possible that a mixed cause of absorption deficiency of vitamin D3 associated with an unbalanced Ca:P diet based on lactose-free milk and fruits may have triggered the disease.
\end{abstract}

INDEX TERMS: Rickets, white-eared opossum, Didelphis albiventris, opossum, metabolic bone disease, pathology, vitamin D, calcium.

RESUMO.- [Raquitismo em gambás-de-orelha-branca (Didelphis albiventris).] Dois gambás jovens foram necropsiados e diagnosticados com raquitismo. 0 objetivo do trabalho é descrever os aspectos clínico-patológicos de raquitismo em Didelphis albiventris. Macroscopicamente os gambás apresentaram cifose e escoliose, desvio lateral dos membros em varus, dificuldade de locomoção e alargamento com amolecimento das junções costocondrais (rosário raquítico). Amostras dos ossos e articulações foram processadas para coloração de hematoxilina e eosina e Tricrômico de Masson. Microscopicamente havia espessamento da placa epifisária, caracterizada pela proliferação irregular e multifocal das

\footnotetext{
${ }^{1}$ Received on February 4, 2020.

Accepted for publication on May 16, 2020.

${ }^{2}$ Laboratório de Patologia Veterinária, Universidade de Brasília (UnB), Via L4 Norte, Brasília, DF 70910-970, Brazil. *Corresponding author: pedrosovet@yahoo.com.br

${ }^{3}$ Faculdade de Medicina Veterinária e Zootecnia (FMVZ), Universidade de São Paulo (USP), Av. Prof. Dr. Orlando Marques de Paiva 87, Cidade Universitária, São Paulo, SP 05508-000, Brazil.

${ }^{4}$ Setor de Animais Silvestres, Hospital Veterinário, Universidade de Brasília (UnB), Via L4 Norte, Brasília, DF 70910-970, Brazil.
}

zonas de cartilagem seriada e hipertrófica, que formavam grupos circulares de condrócitos grandes, displásicos em direção a zona esponjosa frequentemente cercados por tecido osteoide não mineralizado. No osso cortical haviam zonas eosinofílicas pálidas ao redor dos canais de Havers consistentes com osteoide não mineralizado. A coloração de Tricrômico de Masson evidenciou o acúmulo de tecido osteoide no nosso cortical e trabecular. Acredita-se que uma causa mista de déficit de absorção de vitamina D3 associada a uma dieta desbalanceada em Ca:P a base de leite sem lactose e frutas tenha desencadeado a doença.

TERMOS DE INDEXAÇÃO: Raquitismo, gambá-de-orelha-branca, Didelphis albiventris, gambá, doença óssea metabólica, patologia, vitamina D, cálcio.

\section{INTRODUCTION}

Rickets is a metabolic disease that occurs in humans and animals. It is characterized by a deficiency in the mineralization of the physical and epiphyseal cartilage during the endochondral ossification of the newly formed osteoid in young animals 
before the end of growth. It affects bone tissue and growth cartilages, and occurs due to calcium and/or phosphorus deficiency, which can be primary, dietary deficiency, or secondary (Sekarides 2016). Metabolic bone disease (MBD) is one of the terms used to treat diseases that cause bone morphology and functional changes in captive Virginia opossums (Didelphis virginiana). In these animals, the syndrome is usually caused by inadequate diet, $\mathrm{Ca}$ deficiency, or Ca:P imbalance and less likely by vitamin D deficiency (McRuer \& Jones 2009). Vitamin D can be of dietary origins, such as D2 or D3, or the isomerization of 7-dehydrocholesterol (7-DHC) in the skin from ultraviolet light. Herbivores would typically perform this conversion, while carnivores are more dependent on eating other animal's fat. Vitamin D acts on the intestines, bones, kidneys, and parathyroid glands, maintaining the balance between calcium and phosphorus concentrations (Dittmer \& Thompson 2011). In the disease, there is an increase in the volume of bony epiphyses and costochondral junctions, with an accumulation of non-eroded and osteoid cartilage; irregular epiphyseal plate, with delay and alteration of endochondral growth characterized by irregular invasion of the vessels in the growth cartilages, resulting in arching and reduction in bone length; and decreased bone strength, with spontaneous fractures and loss of radiopacity (Craig et al. 2016, Sekarides 2016). Altered skeletal integrity can manifest itself as retarded growth, fractured bones, and/or disturbed calcium and phosphorus levels in the blood (Madson et al. 2012). This study's objective was to describe ricket's clinicalpathological aspects in two free-living opossums (Didelphis albiventris) kept in the hospital.

\section{MATERIALS AND METHODS}

Two male, white-eared, young opossums (Didelphis albiventris) ("Saruê" no. 1 and 2) were referred to the "Laboratório de Patologia Veterinária" of the "Universidade de Brasília" for necropsy. During the necropsy, fragments of various organs and bones of the pelvic, thoracic, and ribs were collected and fixed in $10 \%$ buffered formaldehyde. The fragments were then sent for routine histological processing, embedded in paraffin, cut to $5 \mu \mathrm{m}$ thick, and stained with hematoxylin and eosin (HE). The special Masson's trichrome staining was also performed to show the non-mineralized osteoid matrix and connective tissue proliferation. Additional information was obtained from the requesting veterinarian.

\section{RESULTS}

The white-eared opossums ("saruês") were referred to as puppies for clinical care and, during the first month of life. Lactose-free milk and vitamin D3 supplementation were provided, in addition to fruits supplemented with calcium carbonate. The animals were kept in galvanized cages and without access to sunlight for the same period. In the third month, kyphosis (1/2) and scoliosis (2/2) were observed, in addition to limbs curved in varus in both animals, which promoted locomotor difficulties. Scoliosis and locomotion difficulty of the Saruê 1 made him unable to return to nature, and he died in transport to the Veterinary Hospital. Saruê 2 started to present dyspnea and nasal discharge. Laboratory tests showed an increase in metarrubycites (nucleated red cells), lymphopenia, a marked increase in total alkaline phosphatase 1,119 U/L (mean 11.9 U/L for the species (standard deviation 4.2) (Malta \& Luppi 2007) and a slight reduction in creatinine $(0.3 \mathrm{mg} / \mathrm{dl})$. Treatment with antibiotics was carried out, but there was no success, and due to the worsening of the clinical condition, euthanasia was chosen.

During necropsy, we observed marked curvature of the pelvic and thoracic limbs in varus (Fig.1A), enlargement of the joints, enlargement of the costochondral junctions (rachitic rosary), and spinal deformities (kyphosis and scoliosis). The long bones showed elasticity and softening and, when cut, regular thickening of the epiphyseal plates.

Microscopically, we observed the femur and ribs' metaphysis at the costochondral joint with thickening of the epiphyseal plate, characterized by the irregular and multifocal proliferation of the zones of serial and hypertrophic cartilage, which formed circular groups of large, dysplastic or anucleate (necrotic) chondrocytes. (Fig.2A) towards the spongy area, often surrounded by non-mineralized osteoid tissue. The cortical bone presented pale eosinophilic zones around the Haversian channels consistent with non-mineralized osteoid. The Masson's trichrome stain showed osteoids non-mineralization, staining in blue instead of red compared to a compact, healthy opossum bone (Figs.2C and 2D). Also, the first opossum, in addition to bone alterations, presented a marked multifocal pulmonary lesion, characterized by macrophage infiltration into alveolar spaces and edema.

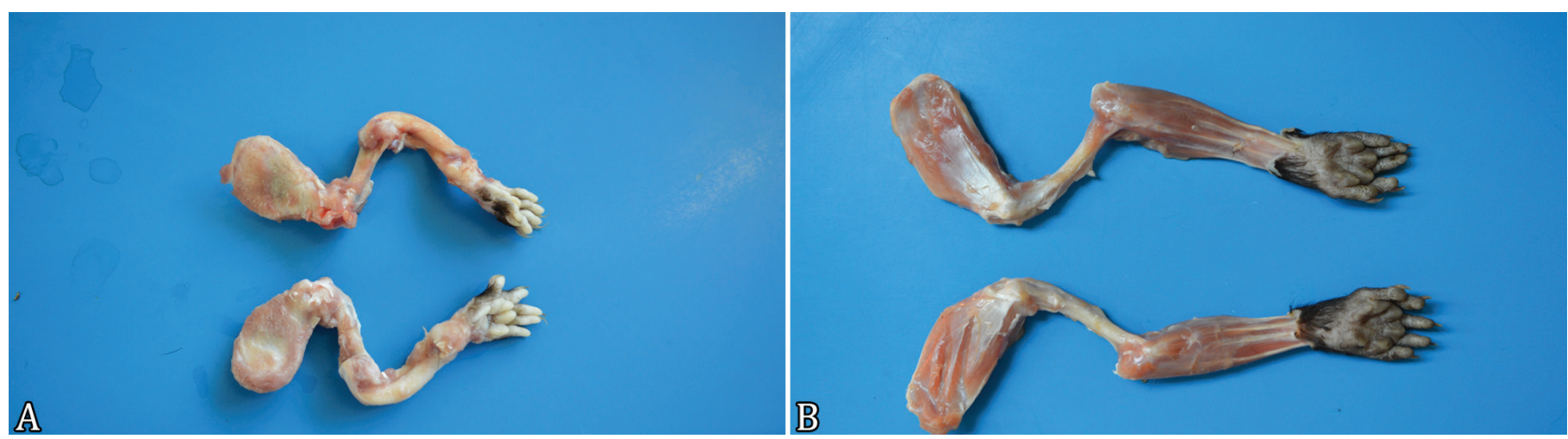

Fig.1. Rickets in white-eared opossums (Didelphis albiventris). (A) Opossum with lateral varus deviation in the thoracic limbs. (B) Normal opossum without curvature of the thoracic limbs. 

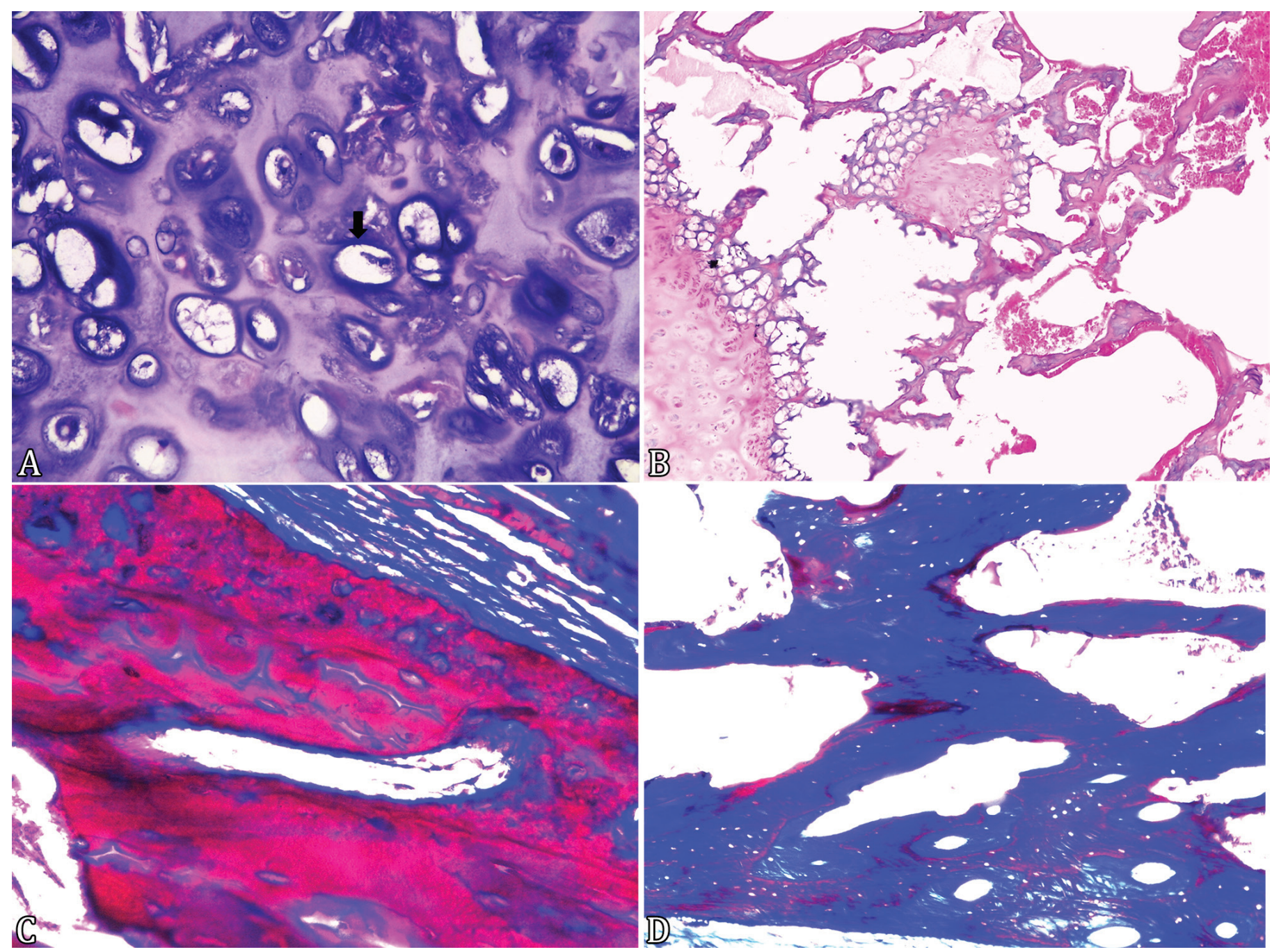

Fig.2. Rickets in white-eared opossums (Didelphis albiventris). (A) Rib metaphysis. Disorganized, large, dysplastic, and sometimes anucleate chondrocytes are noted (arrow). HE, obj.40x. (B) Femur metaphysis with irregular and multifocal proliferation of the serial and hypertrophic cartilage zones. HE, obj.10x. (C) Cortical bone of the femur. A red coloring is noted, representing mineralized bone tissue in a normal opossum of the same age. Masson's trichrome, obj.10x. (D) Cortical bone of the rib. Bone's trabeculae are mostly stained in blue representing non-mineralized and fibrous bone tissue. Masson's trichrome, obj.10x.

\section{DISCUSSION AND CONCLUSION}

The diagnosis of rickets in white-eared opossums ("saruês", Didelphis albiventris) was based on clinical-pathological and epidemiological aspects. MBD that occurs in captive Didelphis virginiana is treated as an entity involving a group of metabolic bone diseases such as osteoporosis, osteomalacia, rickets, imperfect osteogenesis, cage palsy, bone atrophy, juvenile osteoporosis, bone disease, fibrous osteodystrophy, and cystic fibrous osteitis, which have osteopenia and may or may not occur at the same time (McRuer \& Jones 2009). Due to conditions of captivity and the absence of commercial formulations in the opossum's diet, we believe that the imbalance of the Ca:P ratio, with a cholecalciferol bioavailability deficit were determinant for the development of the lesions. The metabolic bone disease supported this hypothesis in opossums currently associated with food that does not reproduce the conditions of nature, mostly related to a calcium deficiency or an inadequate Ca: $P$ ratio in the diet (McRuer \& Jones 2009). However, vitamin D deficiency due to low sun exposure alone would be a less likely cause. Unlike humans, herbivores, pigs, and rats (How et al. 1994, Dittmer \& Thompson 2011), nocturnal mammals such as D. albiventris and other twilight mammals are highly efficient at producing vitamin D3 (cholecalciferol) on the skin with less exposure to sunlight (McRuer \& Jones 2009).

In opossums, the pathogenesis of rickets seems to be similar to what occurs in infants. Studies show some rickets cases attributed to deficient dietary calcium intake in the presence of adequate vitamin D intake. Also, in humans, a low calcium diet is known to exacerbate rickets' development due to vitamin D deficiency in children (Olson \& Carlson 2017).

In addition to the dietary and environmental factors, other unknown causes could be raised for the development of rickets in opossums: hereditary factors or genetic defects of calcium or vitamin D malabsorption. Hereditary cases of rickets resulting from genetic defects have been described in several species, including humans, sheep, pigs (Madson et al. 2012), and domestic cats (Dittmer \& Thompson 2011, Uhl 2018). These genetic mutations have primarily resulted in 
defects in vitamin D synthesis or abnormalities in phosphorus metabolism, supporting the central role of vitamin D and phosphorus in rickets' pathogenesis (Uhl 2018). Although uncommon, a possible phosphorus's primary difficulty was not ruled out in the two opossums since the offered diet's mineral composition is unknown, not supplemented with phosphate. In addition, thickening of the growth plates can directly affect phosphorus deficiency because average serum phosphorus concentrations are necessary for apoptosis of hypertrophic chondrocytes (Craig et al. 2016).

The main clinical sign in both opossums was locomotion difficulty due to bone deformities, which justified euthanasia or prevented the animals from returning to nature. MBD is considered one of the main problems in Didelphidae's orphaned puppies, and clinical signs include locomotion difficulty, inability to climb, bone fragility, fractures, and bone deformities (McRuer \& Jones 2009, Nascimento \& Horta 2014). As the syndrome progresses, systemic changes, such as polyuria, polydipsia, hyposthenuria, and folding fractures in the fingers, long bones, and spine, may occur. Long bones become painful when touched, and the opossum develops a squat posture (McRuer \& Jones 2009). In both cases, bone deformities in the epiphyses were the most evident and justified by the irregular epiphyseal plate with irregular endochondral growth, resulting in arching and reduced bone length (Sekarides 2016). Serum increase in alkaline phosphatase was observed and empirically related to bone disease marker since concomitant liver pathology was not observed (Saraiva \& Lazaretti-Castro 2002).

The anatomopathological findings were similar to those observed in domestic animals. Clusters of hypertrophic chondrocytes in endochondral ossification sites, both in the physis and below the articular cartilage, are histopathological findings characteristic of rickets (Craig et al. 2016). Dysplastic hypertrophic chondrocytes were a finding similar to that described in chondrodysplasias in dogs (Craig et al. 2016) and autosomal recessive hypophosphatemic rickets in Corriedale sheep (JPC 2015). Despite not being pathognomonic, osteoid buildup in the cortical bone was observed histologically and in sheep with rickets (Craig et al. 2016). The animals evaluated presented marked curvature of the pelvic and thoracic limbs and widening of the costochondral junctions. Lesions are typically more severe in the bones that grow faster, including the radius, tibia and metacarpals, and metatarsals (Dittmer \& Thompson 2011). Enlargement of costochondral junctions, the so-called "rickety rosary" is a classic rickets lesion in most domestic species and in children that can be seen on radiographic or post-mortem exams (Craig et al. 2016, Dittmer \& Thompson 2011, Jaffe \& Metabolic 1972, Olson \& Carlson 2017). Masson's trichrome staining proved to be useful to evidence mineralization deficiency. However, like Goldner's trichrome, it should not be used as a diagnostic method alone (Craig et al. 2016).

Rickets in any species must be distinguished from metabolic diseases that develop osteopenia, in addition to arthritis, osteochondrosis, hereditary chondrodysplasias, vitamin A poisoning, or secondary renal hyperparathyroidism. In general, these diseases have ossification defects but not cortical bone mineralization. There are growth deformities and premature closure of growth plates in vitamin A poisoning due to necrosis of chondrocytes and osteoblasts, which leads to reduction in bone mass and non-mineralization (Olson \& Carlson 2017).

Finally, according to the macro and microscopic findings, we conclude that both animals developed rickets, which caused locomotor difficulties and consequent depletion, in addition to secondary diseases.

Acknowledgments.- The authors would like to thank the "Coordenação de Aperfeiçoamento de Pessoal de Nível Superior" (CAPES), Brazil, for granting the scholarship to carry out this work.

Conflict of interest statement.- The author(s) declared no potential conflicts of interest concerning the research, authorship, and/or publication of this article.

\section{REFERENCES}

Craig L.E., Dittmer K.E. \& Thompson K.G. 2016. Bones and joints. p.16-163 In: Maxie M.G. (Ed.), Jubb, Kennedy, and Palmer's Pathology of Domestic Animals. Vol. 1. 6th ed. Vol. 1. Elsevier, St Louis, Missouri.

Dittmer K.E. \& Thompson K.G. 2011. Vitamin D metabolism and rickets in domestic animals: A review. Vet. Pathol. 48(2):389-407. <https://dx.doi. org/10.1177/0300985810375240><PMid:20634407>

How K.L., Hazewinkel H.A. \& Mol J.A. 1994. Dietary vitamin D dependence of cat and dog due to inadequate cutaneous synthesis of vitamin D. Gen. Comp. Endocrinol. 96(1):12-18. <https://dx.doi.org/10.1006/gcen.1994.1154> $<$ PMid:7843559>

Jaffe H.L. 1972. Metabolic, Degenerative, and Inflammatory Diseases of Bones and Joints. Lea \& Febiger, Philadelphia, p.381-448.

JPC 2015. Case I. 9th Wednesday Slide Conference, Joint Pathology Center Veterinary Pathology Service, Maryland. Available at <https://www.askjpc. org/wsco/wsc_showcase2.php?id=Ukg0VXhXQ2djTHJwQjl2a2kvM29CQT09> Accessed on Abr. 02, 2019.

Madson D.M., Ensley S.M., Gauger P.C., Schwartz K.J., Stevenson G.W., Cooper V.L., Janke B.H., Burrough E.R., Goff J.P. \& Horst R.L. 2012. Rickets: case series and diagnostic review of hypovitaminosis D in swine. J Vet Diagn Invest 24(6):1137-1144. <https://dx.doi.org/10.1177/1040638712461487> $<$ PMid:22991390>

Malta M.C.C. \& Luppi M.M. 2007. Marsupialia - Didelmorphia (Gambá, Cuíca). p.340-357. In: Cubas Z.S. (Org.) Tratado de Animais Selvagens: Medicina Veterinária. Vol.1. 1ํed. Roca, São Paulo, SP.

McRuer D.L. \& Jones K.D. 2009. Behavioral and nutritional aspects of the Virginian opossum (Didelphis virginiana). Vet Clin North Am Exot Anim Pract. 12(2):217-236. <https://dx.doi.org/10.1016/j.cvex.2009.01.007> $<$ PMid:19341950>

Nascimento C.C. \& Horta M.C. 2014. Didelmorphia (Gambá, Cuíca). p. 682-707. In: Cubas Z.S. (Org). Tratado de Animais Selvagens: Medicina Veterinária. Vol.1. 2th ed. Roca, São Paulo, SP.

Olson EJ \& Carlson C.S. 2017. Bones, Joints, Tendons and Ligaments. p. 954-1008. In: Pathologic Basis of Veterinary Disease. 6th ed. Elsevier, St. Louis, Missouri.

Saraiva G.L. \& Lazaretti-Castro M. 2002. Marcadores bioquímicos da remodelação óssea na prática clínica. Arq bras endocrinol metab. 46(1):72-78. <https:// dx.doi.org/10.1590/S0004-27302002000100010>

Sekarides R. 2016. Ossos e Articulações. p. 619-663. In: Santos R.L. \& Alessi A.C. (Org). Patologia Veterinária. 2th ed. Roca, Rio de Janeiro, RJ.

Uhl E.W. 2018. The pathology of vitamin D deficiency in domesticated animals: An evolutionary and comparative overview. Int J Paleopathol. 23:100-109. <https://dx.doi.org/10.1016/j.ijpp.2018.03.001> <PMid:29544996> 